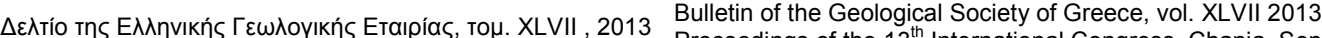

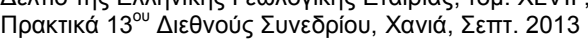

\title{
SPECTROSCOPIC AND THERMAL STUDY OF BENTONITES FROM MILOS ISLAND, GREECE
}

\author{
Bourliva A. ${ }^{1}$, Michailidis K. ${ }^{1}$, Sikalidis C. ${ }^{2}$ and Filippidis A. ${ }^{1}$ \\ ${ }^{1}$ Department of Mineralogy-Petrology-Economic Geology, School of Geology, Aristotle University of \\ Thessaloniki, 54124 Thessaloniki, Greece, annab@geo.auth.gr \\ ${ }^{2}$ Department of Chemical Engineering, Aristotle University of Thessaloniki, 54124 Thessaloniki
} Greece

\begin{abstract}
Bentonitic clays, currently in use in over hundred areas, are among the most important industrial raw materials. In most of the cases, bentonites predominantly consist of montmorillonite which is a 2:1 layer clay mineral formed by one alumina octahedral sheet placed between two silica tetrahedral sheets. Three bentonite composite samples (BN1, BN2, BN3) with some differences in mineralogical and chemical composition from Milos island ("Miloan"), Greece were investigated by $X$-ray diffraction (XRD), atomic absorption spectrometry $(A A S)$, differential thermal analysis (DTA), thermogravimetric analysis (TG), Fourier transform infrared (FTIR) and surface area (BET) measurements techniques. Mineralogically, bentonite samples were characterized by high concentrations of smectite $(>85 \%)$ and minor amounts of other clay minerals (illite and kaolinite). Nonclay minerals such as quartz, calcite and pyrite were also identified. The infrared spectrum of the bentonites also revealed the presence of dioctahedral smectite as the major component and quartz as the main impurity in all the samples. The stretching vibration at $3698 \mathrm{~cm}^{-1}$ in the sample BN3 could be ascribed to kaolinite. DTA-TG curves of all samples were measured in the temperature range $75-1000^{\circ} \mathrm{C}$. The total weight losses for the bentonite samples BN1, BN2 and BN3 were determined as $16.25,12.32$ and $13.35 \%$ respectively.
\end{abstract}

Key words: smectite, Milos, FTIR, DTA/TG.

\section{Пєрí $\eta \psi \eta$}

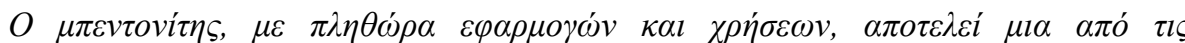

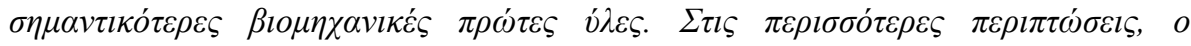
$\mu \pi \varepsilon v \tau o v i t \eta \varsigma$ a

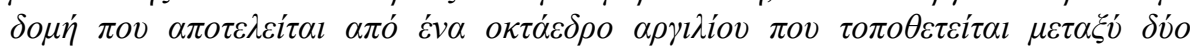

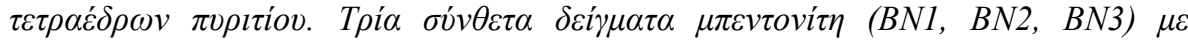

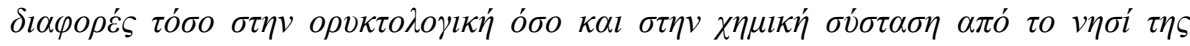

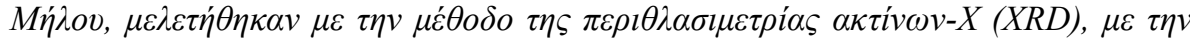

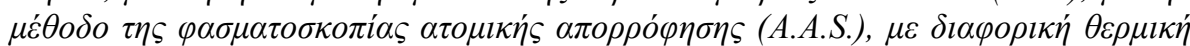

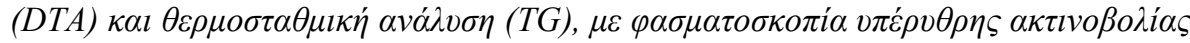

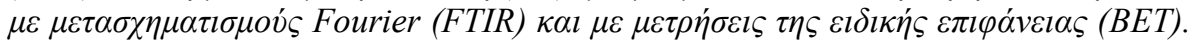

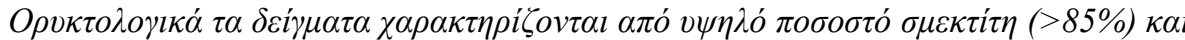

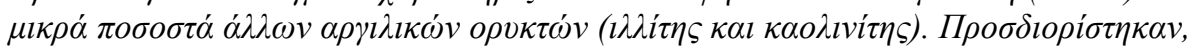

$\underline{\text { XLVII, No 3 - } 2020}$ 


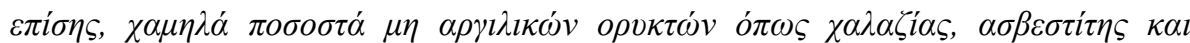

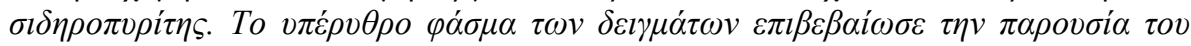

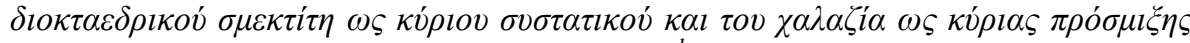

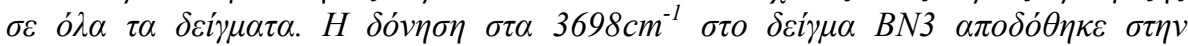

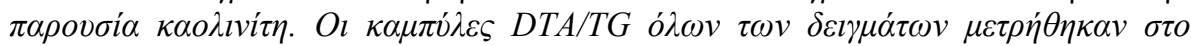

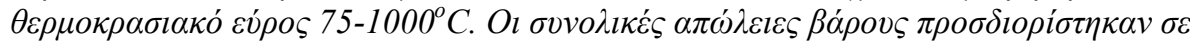

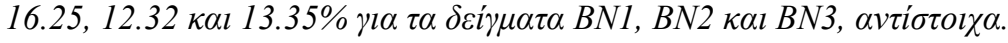

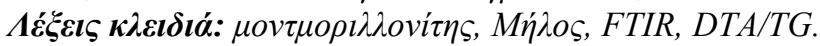

\section{Introduction}

Bentonite, currently in use in over a hundred areas, is among the most important industrial raw materials (Grim and Goven, 1978; Murray, 2000). The dominant mineral in bentonite is montmorillonite which belongs to the smectite group (Grim and Goven, 1978). Smectite is a 2:1 layer clay mineral and has two silica tetrahedral sheets bonded to a central alumina octahedral sheet. Smectites are described either as dioctahedral or as trioctahedral depending upon whether the octahedral cations are predominantly trivalent or divalent, respectively. The net negative electric charge of the 2:1 layers arising from the natural isomorphic substitution of $\mathrm{Fe}^{2+}$ and $\mathrm{Mg}^{2+}$ for $\mathrm{Al}^{3+}$ in the octahedral sites and $\mathrm{Al}^{3+}$ for $\mathrm{Si}^{4+}$ in tetrahedral sites is balanced by the presence of exchangeable cations such as $\mathrm{Na}^{+}$and $\mathrm{Ca}^{2+}$ located between the layers and surrounding the edges (Murray, 2000).

Bentonites are among the most important industrial raw materials and have wide range of uses in many industrial applications like oil, petroleum, cosmetics, ceramics and paintings (Murray, 1991). The application areas of bentonites depend on the quality and quantity of their smectites and other clay and non-clay mineral constituents (Grim, 1968). Some physico-chemical properties of bentonites as well as their mineralogy are greatly affected by thermal treatment. Due to these effects, the investigation of thermal behavior of bentonite samples is of great importance. Additionally, spectroscopic (FTIR) investigation in clay mineral speciation was recently regarded as a useful tool with a multipurpose application, since some physical details of clay lattices and experimental qualitative correlation between the samples were made possible (Davarcioğlu and Çiftçi, 2009).

Greek bentonite is mainly quarried in the north-eastern part of the island, where some of the economically most important bentonite deposits in Europe are concentrated (Kogel et al., 2006). The deposits have been formed by the alteration of Lower Pleistocene volcanoclastic rocks (Christidis et al., 1995). The bentonite reserves are estimated to exceed 20Mt and along with United States, Greece is one of the largest exporters of bentonites. Previous studies on the Miloan bentonites performed at different stages of quarry development, referred on their mineralogy, mode of formation and on their physical properties (Christidis et al., 1995; Christidis and Markopoulos, 1995; Christidis and Scott, 1996; Perraki and Orphanoudaki, 1997). Since information on the evolution of the smectite characteristics in space is very important, representative samples of the Miloan bentonites were used in this investigation. Thus, the aim of this study was to present new data concerning the mineralogical, structural and thermal properties of bentonites from Milos island.

\section{Materials and Methods}

\subsection{Bentonite Samples}

Three natural bentonite samples from W.Ankeria, N.Aspro Horio and S.Aspro Horio deposits of Milos island, coded as $\mathrm{BN} 1, \mathrm{BN} 2$ and $\mathrm{BN} 3$ respectively, were used in the present study. The samples were provided by the S\&B Industrial Minerals S.A. The samples, were ground, sieved to 
obtain the $<63 \mu \mathrm{m}$ particle size fraction, washed with distilled water to remove the soluble salts possibly present and air dried before the experiments.

\subsection{Analytical Methods and Instrumentation}

Chemical analyses of the rock samples were performed by AAS using a Perkin Elmer 5000 apparatus. Sample was crushed in an agate mill till a size $<20 \mu \mathrm{m}$. Then dried for a whole night at $105^{\circ} \mathrm{C} .200 \mathrm{mg}$ of powdered bentonite, weighed with a precision of \pm 0.03 was placed in Teflon autoclaves. Sample dissolution was achieved with the addition of $10 \mathrm{~mL} \mathrm{HF}, 2 \mathrm{~mL} \mathrm{H}_{2} \mathrm{SO}_{4}$ and 1 $\mathrm{mL} \mathrm{HClO}_{3}$. The autoclaves were heated at $110^{\circ} \mathrm{C}$ for $60 \mathrm{~min}$. After being cooled in tap water for about $30 \mathrm{~min}, 5 \mathrm{~g}$ of $\mathrm{H}_{3} \mathrm{BO}_{3}$ were quickly added along with $30 \mathrm{~mL}$ of warm distilled water. The solution was stirred for 5-15 min on a magnetic plate. After this stage the solution was absolutely clear owing to complete dissolution. It was then transferred to a $250 \mathrm{~mL}$ volumetric flask, adjusted to volume and stored in a polyethylene container. From this solution $\mathrm{Si}, \mathrm{Al}$ and $\mathrm{Mn}$ were determined with flame atomic absorption spectroscopy. $10 \mathrm{~mL}$ from the first solution was condensed in an open Teflon vessel until it was completely dry. Then $4 \mathrm{~mL} \mathrm{HCl} \mathrm{1:9} \mathrm{were} \mathrm{added}$ and left to evaporate (this procedure is done twice). Finally, after all the liquid has evaporated, 10 $\mathrm{mL} \mathrm{HCl} \mathrm{1:9} \mathrm{are} \mathrm{added} \mathrm{to} \mathrm{the} \mathrm{solid} \mathrm{residue} \mathrm{along} \mathrm{with} 1 \mathrm{~mL}$ dense $\mathrm{HCl}$. The solution was transferred to a $100 \mathrm{~mL}$ volumetric flask along with $10 \mathrm{~mL}$ of $50 \mathrm{mg} \mathrm{mL} \mathrm{mL}^{-1} \mathrm{LaCl}_{3}$ solution. The solution was adjusted to $100 \mathrm{~mL}$ volume and was used to determine $\mathrm{K}, \mathrm{Na}, \mathrm{Ca}, \mathrm{Mg}$ and $\mathrm{Fe}$ with flame atomic absorption spectroscopy. P and Ti were determined with a Spekol, Carl Zeiss simple beam spectrophotometer. Loss of ignition (LOI) was determined by heating $0.5-1 \mathrm{~g}$ of rock powder for $2 \mathrm{~h}$ at $1050^{\circ} \mathrm{C}$. Detection limits in solution were: Si $1.8 \mu \mathrm{g} \mathrm{mL} L^{-1}, \mathrm{Al} 1.0 \mu \mathrm{g} \mathrm{mL} \mathrm{L}^{-1}, \mathrm{Fe}$ $0.12 \mu \mathrm{g} \mathrm{mL}^{-1}$, Mn $0.055 \mu \mathrm{gL}^{-1}, \mathrm{Mg} 0.007 \mu \mathrm{g} \mathrm{mL}^{-1}$, Ca $0.08 \mu \mathrm{g} \mathrm{mL}{ }^{-1}$, Na $0.015 \mu \mathrm{g} \mathrm{mL} L^{-1}, \mathrm{~K} 0.04$ $\mu \mathrm{g} \mathrm{mL} L^{-1}$.

Mineralogical characterization of the bentonites as well as semi-quantitative mineral determination was performed by X-Ray powder diffraction (XRPD) using a Philips PW1710 diffractometer. Nifiltered copper $\mathrm{K} \alpha$ radiation was used energized to $35 \mathrm{kV}$ and $25 \mathrm{~mA}$, in the range $3-63^{\circ} 2 \theta$ at a scan speed of $1.2^{\circ} / \mathrm{min}$. The characterization of the mineral phases was performed semi-quantitatively on the basis of the intensity (counts) of specific reflections, density, and mass absorption coefficient $(\mathrm{CuK} \alpha)$ of the identified mineral phases.

Infrared spectra of the bentonite samples were recorded $\left(4000-400 \mathrm{~cm}^{-1}\right)$ with Perkin-Elmer FTIR Spectrum 1000 spectrometer at a resolution of $4 \mathrm{~cm}^{-1}$ using $\mathrm{KBr}$ pellet technique. BET surface areas were calculated from the first part of the $\mathrm{N}_{2}$ adsorption isotherm $(\mathrm{P} / \mathrm{Po}<0.5)$ obtained at liquid nitrogen temperature with $\mathrm{N}_{2}$ in Autosorb (Quantachrome Corporation) equipment. Highpurity $(99.99 \%)$ nitrogen was used in adsorption measurements. Simultaneous DTA/TG experiments were carried out using a TA Instrument SD 2960 thermal analyzer. Approximately $15 \pm 2 \mathrm{mg}$ of sample was used in each run. The samples were placed in an alumina crucible and an empty alumina crucible was used as a reference standard. All experiments were performed at a linear heating rate of $10^{\circ} \mathrm{C} \mathrm{min}^{-1}$ over the temperature range of $75-1000^{\circ} \mathrm{C}$.

\section{Results and Discussion}

\subsection{Chemical Analysis}

The results of chemical analyses of bentonite samples are presented in $\mathrm{Table}_{1}$. $\mathrm{SiO}_{2}$ and $\mathrm{Al}_{2} \mathrm{O}_{3}$ constitute the main oxides in the bentonites composition with contents ranging $52.92-60.24 \%$ and $16.97-18.33 \%$ respectively, whereas $\mathrm{TiO}_{2}, \mathrm{MnO}, \mathrm{K}_{2} \mathrm{O}$ and $\mathrm{P}_{2} \mathrm{O}_{5}$ are present only in small quantities. As shown in Table 1, the weight percent of calcium contained in the bentonite samples (1.39$3.05 \%)$ is higher than that of sodium (0.70-1.13\%). The $\mathrm{MgO}$ content ranges between 1.78 and $4.30 \%$. In both cases, the $\mathrm{Fe}_{2} \mathrm{O}_{3}$ content is high (about 5-10\%). 
Table 1 - Chemical analyses (wt \%) of the bentonite samples.

\begin{tabular}{|l|c|c|c|}
\hline Chemical analysis & BN1 & BN2 & BN3 \\
\hline $\mathrm{SiO}_{2}$ & 56.83 & 60.24 & 52.92 \\
\hline $\mathrm{Al}_{2} \mathrm{O}_{3}$ & 16.97 & 18.33 & 18.04 \\
\hline $\mathrm{TiO}_{2}$ & 0.67 & 0.72 & 0.63 \\
\hline $\mathrm{MnO}$ & 0.07 & 0.01 & 0.01 \\
\hline $\mathrm{Fe}_{2} \mathrm{O}_{3}$ & 5.72 & 5.17 & 10.62 \\
\hline $\mathrm{MgO}$ & 4.30 & 3.30 & 1.78 \\
\hline $\mathrm{CaO}$ & 3.05 & 2.02 & 1.39 \\
\hline $\mathrm{Na} \mathrm{O}_{2} \mathrm{O}$ & 1.13 & 0.92 & 0.70 \\
\hline $\mathrm{K}_{2} \mathrm{O}$ & 0.57 & 0.68 & 1.13 \\
\hline $\mathrm{P}_{2} \mathrm{O}_{5}$ & 0.08 & 0.04 & 0.13 \\
\hline L.O.I. (Loss Of Ignition) & 10.63 & 8.60 & 12.40 \\
\hline Total & $\mathbf{1 0 0 . 0 2}$ & $\mathbf{1 0 0 . 0 3}$ & $\mathbf{9 9 . 7 5}$ \\
\hline
\end{tabular}

\subsection{Mineralogical Analysis}

The X-ray diffraction patterns of the bentonite samples are illustrated in Figure 1.
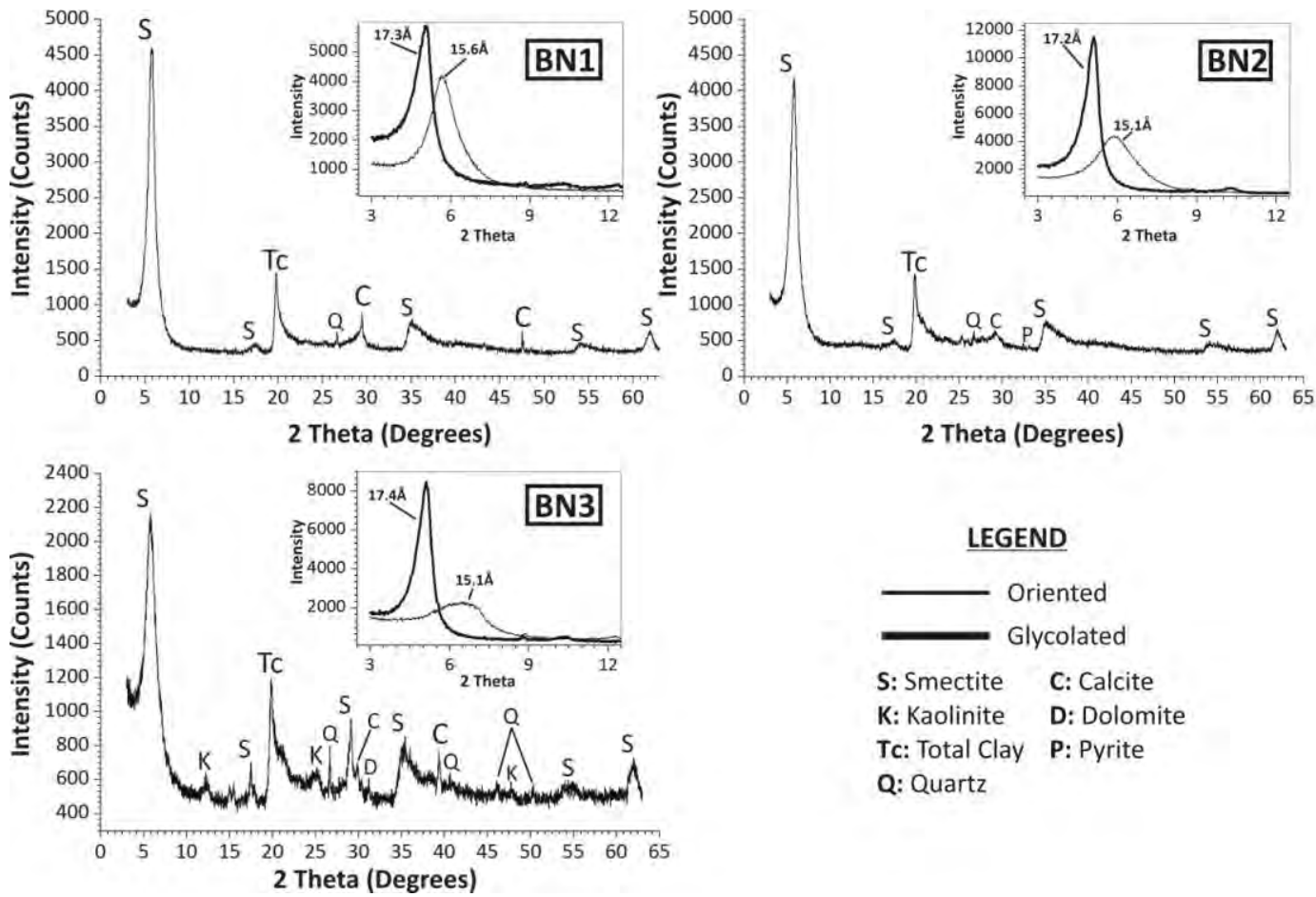

Figure 1 - X-ray diffraction patterns of the bentonite samples (bulk samples). In the detail there are the patterns of the oriented and glycolated samples. 
Bentonites are mainly composed of dioctahedral smectite and specifically Ca-montmorillonite with the $\mathrm{d}_{001}$ basal reflection exhibited at about $15 \AA$ (Figure 1). The estimated smectite contents of the samples were found $94 \%, 97 \%$ and $88 \%$ for the samples BN1, BN2 and BN3, respectively. The BN3 sample additionally contains kaolinite $\left(\mathrm{d}_{001}=7.12 \AA, \mathrm{d}_{002}=3.57 \AA\right)$. Accessory minerals such as quartz $\left(\mathrm{d}_{101}=3.34 \AA, \mathrm{d}_{100}=4.26 \AA\right)$ and calcite $\left(\mathrm{d}_{104}=3.03 \AA\right)$ were detected in all samples. Minor amounts of pyrite $\left(\mathrm{d}_{200}=2.71 \AA\right)$ were present in $\mathrm{BN} 2$ bentonite, and traces of dolomite $\left(\mathrm{d}_{104}=2.88 \AA\right)$ in $\mathrm{BN} 3$ bentonite. Thus, bentonite samples are characterized by high concentration of smectite and low levels of impurities. Similar observations were reported by other authors (Christidis et al., 1995; Perraki and Orphanoudaki, 1997). According to Christidis et al. (1995) dioctahedral smectite is the main phase present in Ankeria and Aspro Horio deposits, while plagioclase is abundant, kaolinite, calcite and zeolites are secondary phases and sulphides are accessory minerals. Perraki and Orphanoudaki (1997) reported that Ankeria bentonite consists mainly of Ca-montmorillonite with minor amounts of calcite, feldspars, quartz, illite and iron sulphides (e.g. pyrite).

\subsection{Specific Surface Area}

The specific surface areas of bentonite samples were determined from the nitrogen adsorption isotherms given in Figure 2. The BET surface areas (obtained by $\mathrm{N}_{2}$ adsorption isotherms at $77 \mathrm{~K}$ ) were 87,67 and $80 \mathrm{~m}^{2} / \mathrm{g}$ for BN1, BN2 and BN3, respectively. BET surface areas of these samples were similar to those found for natural bentonites reported in previous workers (Volzone and Ortiga, 2000; Sakizci et al., 2010).

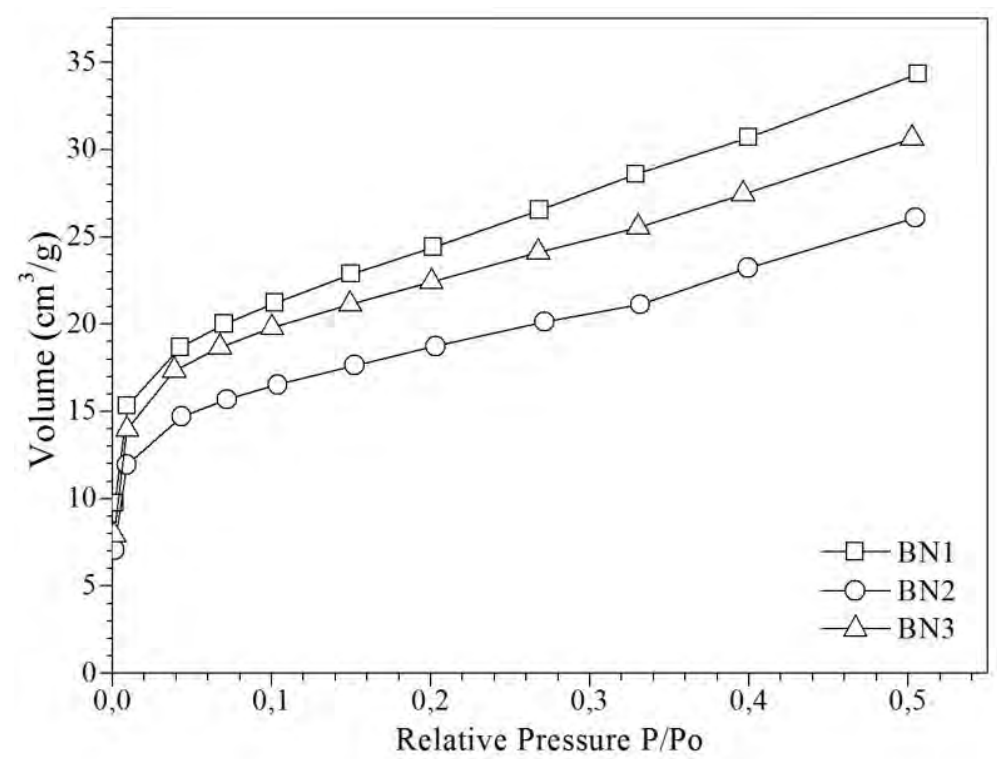

Figure 2 - The isotherms of the adsorption of nitrogen $\left(\mathrm{N}_{2}\right)$ on the bentonite samples.

\subsection{Spectroscopic Study}

FTIR spectra of bentonite samples are shown in Figure 3 and the vibrational modes are summarized in Table 2 together with FTIR data of the Miloan bentonites from previous studies (Christidis et al., 1995; Orphanoudaki and Perraki, 1997) and Wyoming (Tabak et al., 2007) and Ünye, Turkey (Sakizci et al., 2010) bentonites for comparison. Position and shape of the $\mathrm{OH}$ stretching band in the IR spectra of smectites is influenced mainly by the nature of the octahedral atoms to which the hydroxyl groups are coordinated (Madejova, 2003).

The absorption band at 3628,3630 and $3622 \mathrm{~cm}^{-1}$ found in the spectra of BN1, BN2 and BN3 sample respectively, are typical for dioctahedral smectites and is due to stretching vibrations of 

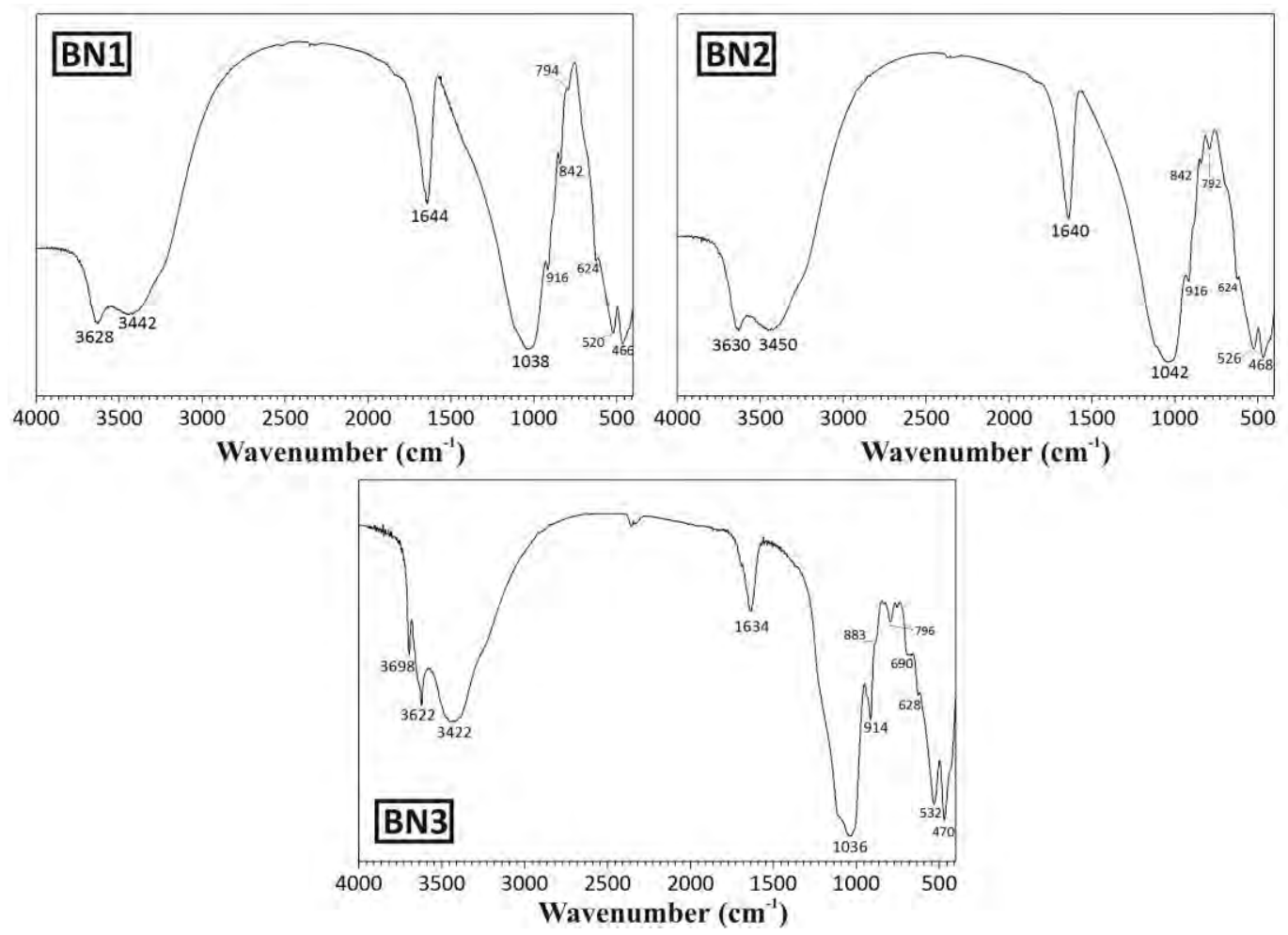

Figure 3 - FTIR spectra of the bentonite samples.

Table 2 - FTIR spectral data of the bentonite samples.

\begin{tabular}{|c|c|c|c|c|c|c|c|c|}
\hline \multirow[b]{2}{*}{ Assignment } & \multicolumn{5}{|c|}{ Data from previous studies } & \multicolumn{3}{|c|}{ Bentonite Samples $\left(\mathrm{cm}^{-1}\right)$} \\
\hline & $1^{a}$ & $2^{b}$ & $3^{\mathrm{c}}$ & $4^{\mathrm{c}}$ & $5^{d}$ & BN1 & BN2 & BN3 \\
\hline $\begin{array}{l}\mathrm{u}(\mathrm{X}-\mathrm{O}-\mathrm{H}) \text { of kaolinite } \\
\text { impurity }\end{array}$ & - & - & - & - & - & - & - & 3698 \\
\hline $\mathrm{u}(\mathrm{X}-\mathrm{O}-\mathrm{H}), \mathrm{X}=\mathrm{Al}, \mathrm{Mg}$ & 3631 & 3630 & 3630 & 3631 & 3620 & 3628 & 3630 & 3622 \\
\hline $\mathrm{u}(\mathrm{H}-\mathrm{O}-\mathrm{H})$ & 3432 & 3450 & 3425 & 3421 & 3400 & 3442 & 3450 & 3422 \\
\hline$\delta(\mathrm{H}-\mathrm{O}-\mathrm{H})$ & 1640 & 1640 & 1635 & 1632 & 1640 & 1644 & 1640 & 1634 \\
\hline $\mathrm{CaCO}_{3}$ impurity & - & - & - & 1426 & - & - & - & - \\
\hline $\mathrm{u}(\mathrm{Si}-\mathrm{O})$ & 1090 & 1087 & 1118 & 1108 & - & - & - & - \\
\hline $\mathrm{u}(\mathrm{Si}-\mathrm{O}-\mathrm{Si})$ & 1045 & 1041 & 1043 & 1054 & - & 1038 & 1042 & 1036 \\
\hline$\delta(\mathrm{Al}-\mathrm{Al}-\mathrm{OH})$ & 919 & 916 & 920 & 919 & 918 & 916 & 916 & 914 \\
\hline$\delta(\mathrm{Al}-\mathrm{Fe}-\mathrm{OH})$ & - & - & 883 & 878 & 875 & - & - & 883 \\
\hline$\delta(\mathrm{Al}-\mathrm{Mg}-\mathrm{OH})$ & 843 & 843 & 848 & - & 845 & 842 & 842 & - \\
\hline $\mathrm{u}(\mathrm{Si}-\mathrm{O})$ of $\mathrm{SiO}_{2}$ impurity & 798 & 795 & 796 & 796 & - & 794 & 792 & 796 \\
\hline $\begin{array}{l}\mathrm{Al}-\mathrm{O}, \mathrm{Si}-\mathrm{O} \text { out of plane } \\
\text { vibrations }\end{array}$ & - & 624 & - & 623 & - & 624 & 624 & 628 \\
\hline$\delta\left(\mathrm{Si}-\mathrm{O}-\mathrm{Al}^{\mathrm{VI}}\right)$ & 524 & 521 & 528 & 525 & 516 & 520 & 526 & 532 \\
\hline$\delta(\mathrm{Si}-\mathrm{O}-\mathrm{Si})$ & 465 & 471 & 467 & 468 & 467 & 466 & 468 & 470 \\
\hline
\end{tabular}

$u$ : stretchnig vibration, $\delta$ : bending vibration

1: Wyoming bentonite, 2: Unye bentonite (Turkey), 3,5: Ankeria bentonite (Milos, Greece), 4: Aspro Horio bentonite (Milos, Greece)

${ }^{a}$ Tabak et al., 2007, ${ }^{b}$ Sakizci et al., 2010, ${ }^{c}$ Christidis et al., 1995, ${ }^{d}$ Perraki and Orphanoudaki, 1997 
structural $\mathrm{OH}$ groups of bentonites (Madejova, 2003; Eren and Afsin, 2008; Caglar et al., 2009; Alabarse et al., 2011; Holtzer et al., 2011). The band at $3698 \mathrm{~cm}^{-1}$ observed in sample BN3 is characteristic for kaolinite which is present as impurity in the sample and is frequently used for identification of kaolinites in raw materials. This band is well separated from absorption bands of most other minerals, which allows identification of very low amounts of kaolinites (Joussein et al., 2001; Madejová et al., 2002). The broad band near $3420 \mathrm{~cm}^{-1}$, observed in the spectra of all samples is due to $\mathrm{O}-\mathrm{H}$ stretching vibrations of adsorbed water, while the bending vibration of water observed at 1644, 1640 and $1634 \mathrm{~cm}^{-1}$, respectively (Xu et al., 2000; Madejova, 2003).

The IR spectra of dioctahedral smectites show only one broad band in the $1040-1020 \mathrm{~cm}^{-1}$ region due to Si-O stretching vibrations. The bands at 916 and $914 \mathrm{~cm}^{-1}$ are attributed to $\mathrm{Al}-\mathrm{Al}-\mathrm{OH}$ bending vibration, while the band at $842 \mathrm{~cm}^{-1}$ observed in the BN1 and BN2 samples corresponds to Al-Mg-OH bending vibration (Madejova, 2003; Eren and Afsin, 2008; Caglar et al., 2009). The peak at $883 \mathrm{~cm}^{-1}$ observed in bentonite BN3 could be ascribed to Al-Fe-OH bending vibration (Madejova, 2003). The appearance of two peaks at about $915 \mathrm{~cm}^{-1}(\delta \mathrm{AlAlOH})$ and about $843 \mathrm{~cm}^{-1}$ $(\delta \mathrm{AlMgOH})$ reflect partial substitution of octahedral $\mathrm{Al}$ by $\mathrm{Mg}$ in the samples BN1 and BN2. Si-O stretching of quartz $\left(\mathrm{SiO}_{2}\right)$ impurity appears at 794,792 and $794 \mathrm{~cm}^{-1}$, respectively (Caglar et al., 2009; Davarcioğlu and Çiftçi, 2009). The bands at 520,526 and $532 \mathrm{~cm}^{-1}$ are due to the $\mathrm{Si}-\mathrm{O}-\mathrm{Al}^{\mathrm{VI}}$ bending band ( $\mathrm{Al}^{\mathrm{VI}}$ is $\mathrm{Al}$ in octahedral positions), while the 466,468 and $470 \mathrm{~cm}^{-1}$ bands to the $\mathrm{Si}$ O-Si bending vibration which is characteristic for smectites (Madejova, 2003). When compared to FTIR data of Miloan bentonites from previous studies (Christidis et al., 1995; Orphanoudaki and Perraki, 1997) and bentonites which have formed in different geological environments like Wyoming and Ünye bentonites, almost identical data were obtained in the present study. Changes in the vibrational frequencies and intensities of $\mathrm{Si}-\mathrm{O}$ peaks must be ascribed to changes in the silicate structure such as $\mathrm{Si}-\mathrm{O}$ bond length, $\mathrm{Si}-\mathrm{O}-\mathrm{Si}$, angle and the angle through which the silica tetrahedra have rotated and the distance between next-nearest oxygens in the basal plane (Sakizci et al., 2010). Weight percentages of chemical compositions and amount of water of the bentonites under study show some differences compared to bentonites from previous studies. Due to these alterations it is not surprising to see some small shifts in the compared data in Table 2.
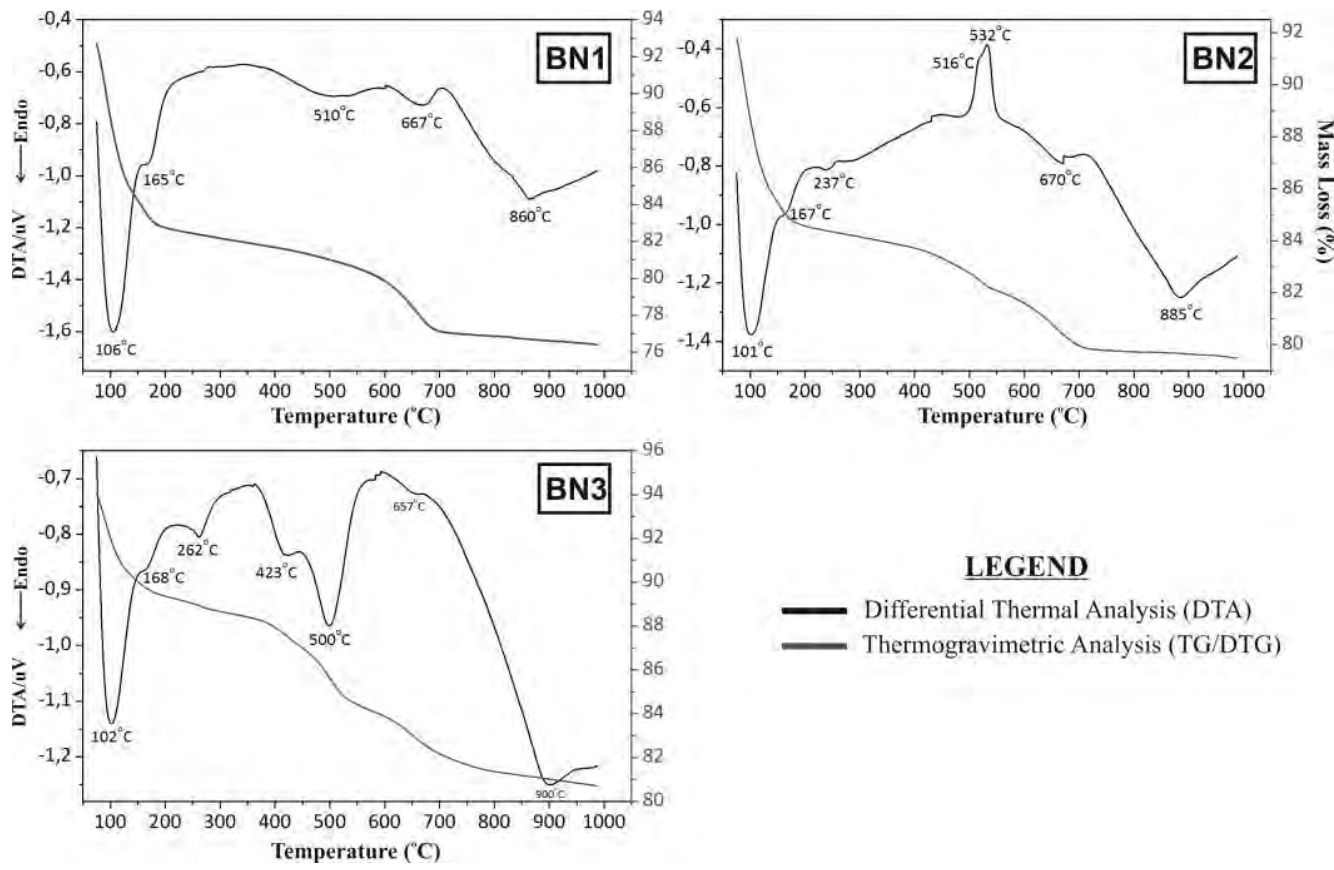

LEGEND

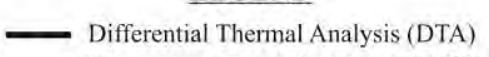

- Thermogravimetric Analysis (TG/DTG)

Figure 4 - Differential thermal analysis (DTA) and thermogravimetric analysis (TG) curves for the bentonite samples.

XLVII, No $3-2026$ 


\subsection{Thermal Properties}

Physical, physicochemical and/or chemical transformation taking place with the application of a thermal effect, are displayed as endo-/exothermic peaks in relation to temperature. Thus, the respective endo- or exothermic peaks shown in DTA curves are very useful ways to establish transformations with or without mass loss and have been used as one of the major tools for qualitative clay characterization (Sakizci et al., 2009). DTA/TG curves of the bentonites are given in Figure 4 for temperature range of $75-1000^{\circ} \mathrm{C}$ and the related mass losses are given in Table 3.

The DTA curves, shown in Figure 4, exhibit a low-temperature strong endothermic peak at $106^{\circ} \mathrm{C}$ for the B1 sample, corresponding to the desorption of physically adsorbed water (Greene-Kelly, 1957; Köster, 1993). There is another very weak endothermic peak, around $165^{\circ} \mathrm{C}$, related to the water molecules bound to $\mathrm{Ca}^{2+}$ cations (Sakizci et al., 2009; Bayram et al., 2010). The endothermic peaks at 510 and $667^{\circ} \mathrm{C}$ represent the dehydroxylation of structural $\mathrm{OH}$ groups (Caglar et al., 2009). The weak endothermic peak at $860^{\circ} \mathrm{C}$ could be ascribed to structure decomposition. Christidis and Markopoulos (1995) reported complete destruction of the smectite structure between $900^{\circ} \mathrm{C}$ and $940^{\circ} \mathrm{C}$. The DTA-TG curve related to the B1 exhibited a total of four mass losses up to $1000^{\circ} \mathrm{C}$ is $16.25 \%$ for the B1 sample.

Table 3 - Thermal analysis (DTA/TG) data of the bentonite samples.

\begin{tabular}{|c|c|c|c|}
\hline \multirow{4}{*}{ Sample } & $\begin{array}{c}\text { Temperature } \\
\text { Range }\left({ }^{\mathbf{}} \mathbf{C}\right)\end{array}$ & $\begin{array}{c}\text { Peak } \\
\text { Temperature }\left({ }^{\mathbf{}} \mathbf{C}\right)\end{array}$ & Mass Loss (\%) \\
\hline \multirow{4}{*}{ BN1 } & $75-140$ & 106 & 8.02 \\
\cline { 2 - 4 } & $140-225$ & 165 & 2.11 \\
\cline { 2 - 4 } & $350-540$ & 510 & 1.26 \\
\cline { 2 - 4 } & $540-725$ & 667 & 3.64 \\
\hline \multirow{5}{*}{ BN2 } & $75-130$ & 101 & 5.59 \\
\cline { 2 - 4 } & $130-225$ & 167 & 1.80 \\
\cline { 2 - 4 } & $350-540$ & $516,532(\mathrm{exo})$ & 1.78 \\
\cline { 2 - 4 } & $540-725$ & 670 & 2.34 \\
\hline \multirow{5}{*}{ BN3 } & $75-125$ & 102 & 3.38 \\
\cline { 2 - 4 } & $125-325$ & 168,262 & 2.14 \\
\cline { 2 - 4 } & $340-450$ & 423 & 1.55 \\
\cline { 2 - 4 } & $450-540$ & 500 & 2.45 \\
\cline { 2 - 4 } & $540-750$ & 657 & 2.87 \\
\hline
\end{tabular}

B2 bentonite sample exhibits four mass loss events on heating in simultaneous DTA/TG (Figure 4 and Table 3). Two dehydration stages with a total mass loss of $7.39 \%$ over the temperature range of $75-225^{\circ} \mathrm{C}$ are noticeable on the TG curve of $\mathrm{B} 2$ sample. The removal of adsorbed water with a mass loss of $5.59 \%$ in the first stage $75-130^{\circ} \mathrm{C}$ gives rise to an endothermic DTA peak centered at $101^{\circ} \mathrm{C}$ and the endothermic peak at $167^{\circ} \mathrm{C}$ in the range of $130-225^{\circ} \mathrm{C}$ which is accompanied by a mass loss of $1.80 \%$ corresponds to the elimination of the water species coordinated to the interlayer cations. The endothermic peak at $670^{\circ} \mathrm{C}$ represents the dehydroxylation of structural $\mathrm{OH}$ groups. The endothermic peak at $670^{\circ} \mathrm{C}$ is associated with $2.34 \%$ mass loss in the range of 540 $725^{\circ} \mathrm{C}$. According to Christidis and Markopoulos (1995) the temperature of the major dehydroxylation for bentonite sample from Aspro Horio quarry was found to be between $685^{\circ} \mathrm{C}$ 
and $690^{\circ} \mathrm{C}$. The two superimposing exothermal reactions at 516 and $532^{\circ} \mathrm{C}$ could be ascribed to the presence of pyrite in this sample (Bonamartini Corradi et al., 1996).

The evolution of adsorbed and cation-coordinated water species in B3 bentonite (Figure 4 and Table 3) is represented by three endothermic peaks at 102,180 and $262^{\circ} \mathrm{C}$, in the range of $75-$ $325^{\circ} \mathrm{C}$ with a $5.52 \%$ mass loss (Figure 4 and Table 3). In DTA plot, a characteristic douplet of endotherms of dioctahedral smectite that appears at 423 and $657^{\circ} \mathrm{C}$ and are accompanied by a total mass loss of $6.87 \%$ in the range of $340-750^{\circ} \mathrm{C}$ denotes dehydroxylation of $\mathrm{B} 3$ bentonite. The strong endothermal reaction at $500^{\circ} \mathrm{C}$ is attributed to the dehydroxylation of kaolinite detected in this sample (Smykatz-Kloss, 1974).

\section{Conclusions}

In the present work, characterization of bentonite samples was performed using XRD, AAS, DTA, TG, FT-IR and surface area measurement methods. The XRD results of this investigation show that the clay deposits from Milos island, mainly consist of smectite and specifically Camontmorillonite with minor amounts of other clay minerals such as illite and kaolinite and quartz and calcite as impurities. The infrared spectrum of these samples confirmed the presence of dioctahedral smectite as the major mineral and quartz as the main impurity. Additionally, kaolinite was detected in the BN3 bentonite sample. The DTA/TG curves of the bentonite samples exhibit intensive endothermal dehydration peaks with one or two shoulders on the side of the peak that faces higher temperatures which characterize smectites with divalent interlayer cations. This comes in agreement with the chemical and mineralogical analysis which proved that the studied bentonites are mainly consisted of Ca-montmorillonites. The dehydroxylation peak doublet between 500 and $700{ }^{\circ} \mathrm{C}$ observed in $\mathrm{BN} 1$ and $\mathrm{BN} 3$ bentonites characterizes smectites with a mixture of both cis- and trans-vacancies in the octahedral sites in contrast to BN2 bentonite which is a smectite with mainly cis-vacant octahedral sheets. The total mass losses up to $1000^{\circ} \mathrm{C}$ for $\mathrm{BN} 1$, $\mathrm{BN} 2$ and $\mathrm{BN} 3$ were determined as $16.25 \%, 12.32 \%$, and $13.35 \%$, respectively.

\section{Acknowledgments}

The authors would like to express their appreciation to the European Social Fund of the European Union and to the Ministry of Education, Lifelong Learning and Religious Affairs of Greece for financing this research in the framework of HERACLITUS II. Additionally, we would like to thank the S\&B Industrial Minerals S.A. company for providing the bentonite samples. Finally, two anonymous referees are fully acknowledged for their valuable comments to the manuscript and their constructive suggestions.

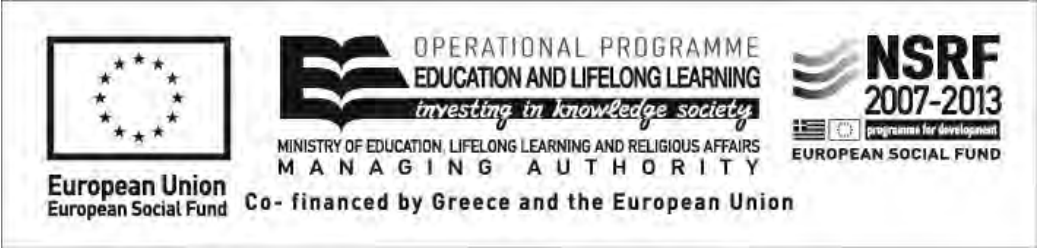

\section{References}

Alabarse F.G., Conceição R.V., Balzaretti N.M., Schemato F. and Xavier A.M. 2011. In-situ FTIR analyses of bentonite under high pressure, Applied Clay Science, 51, 202-208.

Bayram H., Önal M., Yilmaz H. and Sarikaya Y. 2010. Thermal analysis of a white calcium bentonite, Journal of Thermal Analysis and Calorimetry, 101(3), 873-879.

Bonamartini Corradi A., Leonelli C., Manfredini T., Pennisi L. and Romagnoli M. 1996. Quantitative determination of pyrite in ceramic clay raw materials by DTA, Thermochimica Acta, 287, 101-109. 
Caglar B., Afsin B., Tabak A. and Eren E. 2009. Characterization of the cation-exchanged bentonites by XRPD, ATR, DTA/TG analyses and BET measurement, Chemical Engineering Journal, 149, 242-248.

Christidis, G.E. and Markopoulos T. (1995). Mechanisms of formation of kaolinite and halloysite in the bentonite deposits of Milos island, Greece, Chemie Der Erde, 55, 315-329.

Christidis G.E., Scott P.W. and Marcopoulos T. 1995. Origin of the bentonite deposits of eastern Milos, Aegean, Greece: geological, mineralogical and geochemical evidence, Clays and Clay Minerals, 43, 63-77.

Christidis G.E. and Scott P.W. (1996). Physical and chemical properties of bentonite deposits of Milos island, Greece, Transactions Of The Institute Of Mining And Metallurgy, Section B, Applied Earth Science, 105, B165-B174.

Davarcioğlu B. and Çiftçi E. 2009. Investigation of Central Anatolian clays by FTIR spectroscopy (Arapli-Yesilhisar-Kayseri, Turkey, International Journal of Natural and Engineering Sciences, 3, 154-161.

Eren E. and Afsin B. 2008. An investigation of $\mathrm{Cu}(\mathrm{II})$ adsorption by raw and acid-activated bentonite: A combined potentiometric, thermodynamic, XRD, IR, DTA study, Journal of Hazardous Materials, 151, 682-691.

Greene-Kelly R. 1957. The Montmorillonite Minerals (Smectites). In: Mackenzie R. C. (Ed.), The Differential Thermal Investigation of Clays. Mineralogical Society, London.

Grim R.E. 1968. Clay Mineralogy, $2^{\text {nd }}$ Ed., McGraw Hill, New York.

Grim R.E. and Góven N. 1978. Bentonites, Geology, Mineralogy, Properties and Uses: Development in Sedimentology, Elsevier, Amsterdam.

Holtzer M., Bobrowski A. and Zymankowska-Kumon S. 2011. Temperature influence on structural changes of foundry bentonites, Journal of Molecular Structure, 1004, 102-108.

Joussein E., Petit S. and Decarreau A. 2001. Une nouvelle méthode de dosage des minéraux argileux en mélange par spectroscopie IR, Comptes Rendus de l'Académie des Sciences, $332,83-89$

Kogel J.E., Trivedi N.C., Barker J.M. and Krukowski S.T. 2006. Industrial minerals and rocks: commodities, markets, and uses, Society for Mining, Metallurgy, and Exploration, INC. (SME), USA.

Köster H. M. 1993. Dreischichtminerale oder 2:1 Schichtsilikate. In: Jasmund K. \& Lagaly G. (Eds.), Tonminerale und Tone. Darmstadt: Steinkopff Verlag.

Madejova J. 2003. FTIR techniques in clay mineral studies, Vibrational Spectroscopy, 31, 1-10.

Madejová J., Kečkéš J., Pálková H. and Komadel P. 2002. Identification of components in smectite-kaolinite mixtures, Clay Minerals, 37, 377-388.

Murray H.H. 1991. Overview-clay mineral applications, Applied Clay Science, 5, 379.

Murray H.H. 2000. Traditional and new applications for kaolin, smectite and palygorskite: a general overview, Applied Clay Science, 17, 207.

Perraki T. and Orphanoudaki A. (1997). Etude de la composition mineralogique et de proprietes phisiques des bentonites de l'ile de Milos (Grece), Mineral Wealth, 104, 35-42.

Sakizci M., Alver B.E., Alver O. and Yörükoğullari E. 2010. Spectroscopic and thermal studies of bentonites from Ünye, Turkey, Journal of Molecular Structure, 969, 187-191.

Sakizci M., Alver B.E. and Yörükoğullari E. 2009. Thermal behaviour and immersion heats of selected clays from Turkey, Journal of Thermal Analysis and Calorimetry, 98, 429-436.

Smykatz-Kloss W. 1974. Differential Thermal Analysis, Springer-Verlag, Berlin, 185 pp.

Tabak A., Afsin B., Caglar B. and Koksal E. 2007. Characterization and pillaring of a Turkish bentonite (Resadiye), Journal of Colloid and Interface Science, 313, 5-11.

Volzone C. and Ortiga J. 2000. $\mathrm{O}_{2}, \mathrm{CH}_{4}$ and $\mathrm{CO}_{2}$ gas retentions by acid smectites before and after thermal treatment, Journal of Materials Science, 35(21), 5291.

Xu W., Johnston C.T., Parker P. and Agnew S.F. 2000. Infrared study of water sorption on Na-, Li-, Ca-, and Mg-exchanged (SWy-1 and SAz-1) montmorillonite, Clays and Clay Minerals, 48, 120-131. 